\title{
ANALYSIS OF MIXED INDONESIAN LANGUAGE WITH OTHER LANGUAGES ON SOCIAL MEDIA
}

\author{
Pricillia Catur Rizkyna ${ }^{1}$, Merlina Dewi Khaerun Nisa ${ }^{2}$, Andini Nur Aulia ${ }^{3}$ \\ ${ }^{1,2,3)}$ English Language and Literature, Faculty of Humanities, Airlangga University \\ pricillia.catur.rizkyna-2020@fib.unair.ac.id; merlina.dewi.khaerun- \\ 2020@fib.unair.ac.id; andini.nur.aulia-2020@fib.unair.ac.id
}

Corresponding Author: Dr. Moses Glorino Rumambo Pandin, M.Si., M.Phil

$\underline{\text { moses.glorino@fib.unair.ac.id }}$

\begin{abstract}
Indonesian is a national and unity language for Indonesian people. Every day, Indonesian people use Indonesian as the primary language to communicate with others. In this era of digitalization, the use of the Indonesian language on social media is inseparable. In social media language style, everyone has their way. One of them is using the language mixture while communicating on social media. Indonesian people often mix the Indonesian language with other languages such as local language and foreign language. Based on this situation, this research aims to provide facts and analyze the use of language mixture between the Indonesian language and other languages on social media. The method research is descriptive qualitative with observation through 5 social media platforms such as Facebook, Instagram, Tiktok, Twitter, and Youtube. The results of this research are 50 data from 5 social media platforms that mixed the Indonesian language with other languages. This research has limitations that are, the data observation-only observed 5 social media platforms and got only 50 data of mixedlanguage.
\end{abstract}

Keywords: Mix, Language, Social Media

\section{INTRODUCTION}

In this era of digitalization through social media, people can connect with other people around the world. Definition of social media is defined in several ways. (1) In practice, social media is a collection of software-based digital technologies - usually displayed as apps and websites - that provide users with digital environments that can transmit and receive digital content or information through various forms of online social networks. (2) Social media is also defined as Internet-based group applications that construct on the ideological and technological foundations of Web 2.0 that authorize the creation and exchange of usergenerated content. Social media has various platforms and features, such as Facebook, Instagram, TikTok, Twitter, Youtube, etc.

On social media, people communicate with others using different languages. (3) Language is the prime communication tool for humans to provide information and socialize with others, and humans can provide ideas or ideas needed for social interaction. Definitionally, 
language is one of the critical elements of culture. (4) Language is a system of arbitrary sound symbols used by people to collaborate, interact and identify themselves. As an element of culture, language represents social changes during its user community. The dynamics of language users can be used as an indicator of how the dominance of certain cultures over other cultures in society. (5) Language consists of contexts that are also simultaneously related. In this stage, the language produced in various forms is a cultural product that is inseparable from the context of the space-time of the culture concerned.

In Indonesia, the Indonesian language is the primary language. The Indonesian language is the state language as stated in the 1945 Constitution of the Republic of Indonesia. Indonesian is the language used by the public to communicate, including social media. (6) Language is inseparable from society itself. All social media users can see the way people use the language. In this case, language is the main element that is very important because language is an identity of a community group.

Social media often presents a new phenomenon in society. The public normalized many changes. One of them is that the language style does not match the rules of the Indonesian language. (7) Although there is no requirement or standard rule to use Indonesian according to the rules while communicating on social media. For example, people often mix Indonesian with foreign languages or regional languages. (4) Language mixing is due to bilingualism and multilingualism. (4) The definition of bilingualism is using two languages with a speaker in life. Meanwhile, multilingualism uses more than two languages in a person's social life with other people. Both bilingualism and multilingualism refer to using two or more languages by a person interchangeably.

The situation shows the mixture of the Indonesian language and another language. (8)Mix is defined as combined or integrated. So, in this situation, mixed language means combining or integrating one language with another language. The situation about the mixeduse of Indonesian and other languages on social media is interesting to analyze.

\section{RESEARCH METHOD}

This research used a descriptive qualitative method. (9) Qualitative research is an investigation strategy that accentuates the search for the mean, conception, concept, characteristics, symptoms, symbols, and descriptions of a phenomenon. It is focused and multimethod, natural and holistic, prioritizes quality, and presents narratively. It is said that the goal of qualitative research is to find answers to a phenomenon or question through the systematic use of scientific procedures using a qualitative approach. The descriptive method is a method of research that attempts to describe and interpret the objects by reality (10).

The data collecting method for this research is observation. It is a collection of data methods through the human senses by observing social phenomena and recording events that occur. The observation was conducted on five different social platforms including, Facebook, Instagram, Tiktok, Twitter, and Youtube. This research observed the implementation of the mixed language in posts, captions, and comments. 
The collected information and data are processed by observing the data from social media, analyzing the form of language that people used, and sorting the data according to the content of the concept to be researched.

Data analysis is the process of systematically searching and compiling the data received from interviews, field notes, and other materials so that they can easily understand and share the findings with others (11). In this article, the theory that is based on the three stages, reduction of this research was carried out through three stages, reduction, display data, and drawing a conclusion. The reduction was carried out to determine relevant, meaningful, and important data based on the research conducted and to obtain the data that researchers needed. The display data obtained in this study are presented in the form of a short narrative description (with text). Drawing conclusions (verification) researchers will draw or make conclusions by providing an explanation of data collection through observation of data on social media (12).

\section{RESULTS}

The results of this research consist of 50 data from 5 different social media platforms, namely Facebook, Instagram, TikTok, Twitter, and Youtube. From each of those platforms obtained 10 data observations of the mixed-use of Indonesian and other languages. This data contains mixed usages of Indonesian and other languages.

\begin{tabular}{|l|c|c|c|c|c|c|}
\hline \multirow{2}{*}{ Platform } & \multicolumn{7}{|c|}{ Mixed Language Form } \\
\cline { 2 - 7 } & $\begin{array}{c}\text { Indonesian } \\
\text { - English }\end{array}$ & $\begin{array}{c}\text { Indonesian } \\
\text { - Arabic }\end{array}$ & $\begin{array}{c}\text { Indonesian } \\
\text { - Javanese }\end{array}$ & $\begin{array}{c}\text { Indonesian } \\
\text { - Turkish }\end{array}$ & $\begin{array}{c}\text { Indonesian - } \\
\text { English - } \\
\text { Javanese }\end{array}$ & $\begin{array}{c}\text { Indonesian - } \\
\text { Javanese - } \\
\text { Sundanese }\end{array}$ \\
\hline Instagram & 8 & & 1 & 1 & & \\
\hline Tik Tok & 10 & & & & & 1 \\
\hline Twitter & 8 & & 1 & & & 1 \\
\hline Facebook & 8 & & 1 & & & \\
\hline Youtube & 7 & 2 & 1 & & & \\
\hline
\end{tabular}

Based on the observation data, researchers found 41 out of 50 uses of mixed Indonesian and English with the following details: 8 data from Instagram, 10 data from Tiktok, 8 data from Twitter, 8 data from Facebook, and 7 data from Youtube. This mixture of languages is the most commonly used on social media. Furthermore, 2 out of 50 data use a mix of Indonesian and Arabic. Those data were found on Youtube. Meanwhile, 4 out of 50 data use a mixture of Indonesian and Javanese. Each of those, found on the social media platforms Instagram, Twitter, Facebook, and Youtube. Then the other results showed that 1 of 50 was found on Instagram by mixing Indonesian with Turkish.

On the other hand, this research found the phenomenon of mixing three languages. The first is a mixture of Indonesian, English, and Javanese. Then, this research found 1 of 50 data. This mixture of language was found on Facebook. The other phenomenon of mixing three languages is a mixture of Indonesian, Javanese, and Sundanese. This data was found on Twitter. 


\section{DISCUSSION}

The data analysis below focuses on analyzing the use of language variations in terms of speech and terms formality. In addition, the analysis of the use of mixed data between Indonesian and other languages uses an analysis based on the words meaning in Indonesian.

The data that has been collected regarding the example use of mixed Indonesian and other languages on social media:

1. Mixed language of Indonesian and English

$1^{\text {st }}$ Data: Existing famous story on Wattpad brought to life into a series. Ada yang bisa tebak aku peranin karakter siapa? (Existing famous story on Wattpad was brought to life in a series. Can anyone guess what character that I play?)

$2^{\text {nd }}$ Data: Memang Pele selalu out of the box bikin sesuatu (Absolutely, Pele is always out of the box when making something)

$3^{\text {rd }}$ Data: ...and everyone's screaming astaga dan secara ngga langsung kakaknya ngerendahin ( ...and everyone's screaming oh my god and indirectly her sister underestimate her)

$4^{\text {th }}$ Data: yes, helping others itu menyenangkan sekali, that amazing feeling afterwards (yes, helping others is very exciting, that amazing feeling afterward)

$5^{\text {th }}$ Data: Yaudach. Instead of masukin motor ke ruang tamu tiap malem, how about telling maling not to maling motor $u$ ?..... (okay then, instead of taking a motorcycle in the living room every night, how do you tell the thief not to steal your motorcycle?)

$6^{\text {th }}$ Data: Real definition of all fun and games banget (The real definition of all very fun and games)

$7^{\text {th }}$ Data: ....Semoga Lau selalu diberi kesehatan dan kesabaran dlm menjalani ini semua. I know you are strong than we think (I hope Lau has always given health and patience through all of this. I know you are stronger than we think)

$8^{\text {th }}$ Data: Requestnya kami berdua kabulkan.. selamat menonton dan have a nice weekend (We both granted the request... happy watching and have a nice day)

$9^{\text {th }}$ Data: Setiap lihat konten nya ria, positive vibes terus yang didapat, dan kontennya asik dan humble... Sehat terus orang baik (Every time I see Ria's content, I always get positive vibes, and her content is fun and humble)

$10^{\text {th }}$ Data: Oh 1 more, if u think that i'm the one who "SEBAR" info ke admin2 tiktok bahkan sampe bayar mereka. I dont think $i$ need to pay them. If im the bad guy $i$ could just share bukti with my account. But what? I choose not to. Cause i care about 
u. And her. (Oh! one more, if you think that I am the one who "SPREAD" information to TikTok admins and even paid them. I do not think I need to pay them. If I am the bad guy, I could just share evidence with my account. But what? I choose not to. Cause I care about you. And her)

$11^{\text {th }}$ Data: Jangan lupa aktifin notifikasi ig yas. Yuhuu, get ready to grab yours (Don't forget to turn on your instagram notification. Yuhuu, get ready to grab yours)

$12^{\text {th }}$ Data: The way gita udah meledak2 sambil give a reaction,.... (The way the Gita explodes while giving a reaction,....)

$13^{\text {th }}$ Data: Just finished following up a case dan sumpah sakit banget..she was strong but this world was so harsh for her (Just finished following up on a case, and I swear it is hurting...she was strong, but this world was so harsh for her

$14^{\text {th }}$ Data: What????!! SEE YOU IN SEOUL ???!??!?! March 2020 let's go aaa! Aku akan open concert trip (What?! See You in Seoul! let's go on March 2020, I will open concert trip)

$15^{\text {th }}$ Data: Nagita Slavina ini emang smart banget. She's the real backbone of her family (Nagita Slavina is very smart. She is the real backbone of her family)

$16^{\text {th }}$ Data: Dufan itu maskotnya bekantan, and they do nothing wrong kak. Dia banyak bestienya baik budi dan kesayangan rakyat Indonesia. (Dufan icons are proboscis monkeys, and they do nothing wrong. It has a lot of friends, has a good attitude, and is a favorite of Indonesian people)

$17^{\text {th }}$ Data: Orang Lain Mah Pada Ngeshare Foto Bareng Pacar,Lah Gue Ngeshare Status Mulu (Someone else often shares their picture with their girl or boyfriend, while I just keep on sharing my status)

$18^{\text {th }}$ Data: Beberapa orang dipertemukan hanya untuk menjadi penonton story, bukan untuk menjalin story. (Some people meet just for being story viewers, not to build a story)

$19^{\text {th }}$ Data: Mom, I'm so tired of all this... But, aku punya banyak impian yang harus $d$ gapai... (Mom, I'm so tired of all this... But, I have a lot of dreams that should I reach)

$20^{\text {th }}$ Data: Another motivasi, "udh kalah dr segi ekonomi, jangan kalah dr segi pendidikan $j g$ ", thanksss jerome (Another motivation, "if you have lost in terms of economy, don't lose in terms of education too", thanks Jerome)

Those are 20 of the 41 data found on social media used mixed Indonesian and English. (13). Indonesian is more varied with the combination and addition of English or from English 
which is absorbed into Indonesian so that there is also the Indoglish phenomenon (IndonesianEnglish).

Then adding the Indoglish language (Indonesian-English) is a term frequently used in English, which is still a variation in Indonesian culture and language (14). Indoglish is a distinctive and unique form of language, whereas the current form is a blend of English and Indonesian (15). Indoglish is a particular form because specific communities in society often use it. The combination of Indonesian and English, which are used together, gives a distinctive impression and is identical to the lives of particular communities closely related to academic life and have high intellectual abilities.

The mixture of the two languages (Indonglish) is the most widely mixed language used by people on social media. Generally, the Indonesian language used is informal language or contemporary slang. The use of English in mixed language situations varies. English is usually placed at the beginning, inserted in the middle, or at the end. It depends on the context of the sentence used by the user.

2. Mixed language of Indonesian and Arabic

$1^{\text {st }}$ Data: Masyaallah.. alhamdulillah brp nyawa terselamatkan $d g$ wasilah bp polisi yang sudah memperingatkan penambang pasir...

$2^{\text {nd }}$ Data: Masyaallah tabarokallah udah terjamin pendidikannya rayyanza, smoga nular rejekinya, Aamin.

The data shows a mixture of Indonesian and Arabic. (16) "Masha Allah" is an Arabic phrase. This word is used to express admiration for something. "Masha Allah" is often followed by the word "Tabarakallah," which means may Allah bless you. Another word is "Alhamdulillah" or Tahmid. "Alhamdulillah" is an Arabic phrase that means that praise belongs only to Allah. That word refers to an expression of gratitude. Then, "wasilah" is an Arabic loan word. (17) The word "wasilah" means; communication; ties. Lexically way; tool; instrument. In this case, there is a change in total meaning that has no relevance to the previous (18). The Muslim community generally uses those Arabic words.

3. Mixed language of Indonesian and Javanesse

$1^{\text {st }}$ Data: Melihat kebersamaan mereka jalan-jalan nang ndeso ikutan happy

$2^{\text {nd }}$ Data: Cah pinter tenan iki..salut sama pemikirannya anak muda yang penuh semangat

$3^{\text {rd }}$ Data: Plonga plongo, eh ga kerasa bentar lagi tahun baru.

$4^{\text {th }}$ Data: Siapa kira-kira yang melindungi? Saya jadi ber takon takon

The data above shows a mixture of Indonesian and Javanese. The Javanese language is placed at the beginning, at the end, or in the middle. Some sentences that indicate a mixture of 
Javanese language include "nang ndeso" which means "to the village", then "Cah pinter tenan iki" which means "this brilliant child", "Plonga plongo" which means dumbfounded, and "takon" which means ask. In the sentence, the word "Cah" is usually spoken by people in the Mataraman dialect Javanese language coverage area. The area includes the former territory of the Residency (19).

4. Mixed language of Indonesian and Turkish

$1^{\text {st }}$ Data: Merhaba mau tau dong kalian postingan aku yg ini ketika kalian lagi dimana? Dan lagi ngapain?

The data shows a mixed sentence pattern of Indonesian and Turkish. At the beginning of the sentence, there is "Merhaba" which means Hello. Then speakers use informal Indonesian marked by the words "mau" which means want, "dong" which does not have meaning, and "ngapain" which means what are you doing.

5. Mixed language of Indonesian, Sundanese, and Javanese

$1^{\text {st }}$ Data: Rek bales bahasa enggres yokpo? Iyo aku sing njupuk videone, sok atuh ambil aja. Gosah permisi2an

The data showed a mixture of Indonesian-Sundanese-Javanese. At the beginning of the sentence, speakers use Javanese Arekan dialects. It is characterized by the presence of the words "rek" which means guys or friends, "yokpo" which means how, and "njupuk" which means take. Then in the middle, speakers slip the Sundanese language "sok atuh" which means, please. It ends with informal Indonesian.

Overall, that mixture of the three languages in Indonesian means "Guys how to reply with English? Yes, I took the video, please just take it? No need to excuse me."

6. Mixed language of Indonesian, English, and Javanese

$1^{\text {st }}$ Data : Buat apa mikirin orang selalu nganggap kita biasa aja hiii nggilani poll lapo biyen areke dadi koncoku tapi slamet udah bye maximal

The data shows a mixture of Indonesian-English-Javanese. Overall, the Indonesian language is used as an informal language marked by the words "mikirin" means thinking, "nganggap" means assume, "aja" means only, and "udah" means already.

The Javanese language used in the data uses the Arekan dialect. Most of the regions that use the Arekan dialect are Malang, Pasuruan, Surabaya, Gresik, Mojokerto. (19). In the data, it showed by the word "nggilani poll" that means disgusting, "lapo" generally in the Javanese language is "ngopo" that means what are you doing, and the things that characterized this language with others is the word "areke" that means his or her.

Then, at the end of the sentence, the speaker also mixes with English. This is indicated by the words "bye" and "maximal." In this context, it refers to the meaning of goodbye forever. 
So, in the complete Indonesian sense, the sentence means "Why to think about people who always think we are standard. It is very disgusting. Why did he become my friend in the past, but fortunately he has been left forever".

\section{CONCLUSION}

Based on the research, the conclusion is that one of the language styles used by people on social media is a mixed language, where mixed-languages are mixing Indonesian with other languages. Then, based on the analysis in mixed language writing, people tend to combine two to three languages in one sentence, such as a mixed language of Indonesian with English, Indonesian with Arabic, Indonesian with Turkish, Indonesian with English and Javanese, and Indonesian with Sundanese and Javanese. The words used can have meaning according to the context of the speaker's sentence. The most common mix of languages found is a mixture of Indonesian and English. In addition, Indonesian people tend to use informal Indonesian in social media, then mixed with other languages.

This research cannot stand up without limitations. Based on the experience of this research, some of it can be a concern for future research to make it more perfect. There were only 50 samples of observational data from 5 different social media platforms in this research. In addition, this study only analyzes the mixed language styles used by Indonesian people in communicating on social media.

Thus, based on the research results, which only discusses the analysis forms of mixeduse of Indonesian and other languages on social media. In this case, studies and research need to analyze the factors that cause someone to use a mixture of Indonesian and other languages on social media. Therefore, for the next researcher, we provide recommendations and suggestions to study and investigate further the factors that influence why someone uses mixed language on social media.

\section{REFERENCES}

1. Appel, G., Grewal, L., Hadi, R., \& Stephen, A. T. (2020). The future of social media in marketing. Journal of the Academy of Marketing Science, 48(1), 79-95.

2. Kaplan, A. M., \& Haenlein, M. (2010). Users of the world, unite! The challenges and opportunities of Social Media. Business horizons, 53(1), 59-68.

3. Rahmadina, B. (2019). Penggunaan Variasi Bahasa Dalam Media Sosial Instagram Pada Akun@ Awkarin: Kajian Sosiolinguistik (Doctoral dissertation, Universitas Airlangga).

4. Ramadhanti, T. Y. A. (2020). Variasi Bahasa Pada Akun Youtube Korea Reomit: Kajian Sosiolinguistik (Doctoral dissertation, Universitas Airlangga).

5. Susanto, T. T., Atmaja, J., Nurdiansyah, C., \& Alam, N. (2019). Mengungkap Fenomena Bahasa Campuran Pada Budaya Populer dalam Perspektif Postmodern. Jurnal Trias Politika. Jurnal Trias Politika, 3(2), 170-181.

6. Bulan, D. R. (2019). Bahasa Indonesia Sebagai Identitas Nasional Bangsa Indonesia. JISIPOL. Jurnal Ilmu Sosial Dan Ilmu Politik, 3(2), 23-29. 
7. Arsanti, M., \& Setiana, L. N. (2020). Pudarnya Pesona Bahasa Indonesia di Media Sosial (Sebuah Kajian Sosiolinguistik Penggunaan Bahasa Indonesia). Lingua Franca: Jurnal Bahasa, Sastra, dan Pengajarannya, 4(1), 1-12.

8. Kbbi.kemdikbud.go.id. (2016). KBBI Kemdikbud. Accessed from https://kbbi.kemdikbud.go.id/

9. Sidiq, U., Choiri, M., \& Mujahidin, A. (2019). Metode Penelitian Kualitatif di Bidang Pendidikan. Journal of Chemical Information and Modeling, 53(9).

10. Ahsan, W. (2015). Cohesive Devices In Selected Short Stories Retold by Slamet Riyanto. IAIN Tulungagung.

11. Ahsanulkhaq, M. (2019). Membentuk Karakter Religius Peserta Didik Melalui Metode Pembiasaan. Jurnal Prakarsa Paedagogia, 2(1), 21-33.

12. Latifah, N., \& Supena, A. (2021). Analisis Attention Siswa Sekolah Dasar Dalam Pembelajaran Jarak Jauh di Masa Pandemi Covid-19. Jurnal Basicedu, 5(3), 1175-1182.

13. Rahardi, R. K. (2017). Bahasa 'Indoglish' dan 'Jawanesia' dan Dampaknya Bagi Pemartabatan Bahasa Indonesia. Kajian Linguistik dan Sastra, 26(1), 1-21.

14. Saddhono, K. (2017). Bahasa dan Etika dalam Sosial Media: Kajian Sosiolinguistik di Perguruan Tinggi Indonesia. Prosiding Konferensi Nasional Bahasa dan Sastra IV, 248254.

15. Oktavia, W. (2019). Eskalasi bahasa indoglish dalam ruang publik media sosial. Diglosia: Jurnal Kajian Bahasa, Sastra, dan Pengajarannya, 2(2), 83-92.

16. Ninsi, R. A., \& Rahim, R. A. (2020). Alih Kode dan Campur Kode pada Peristiwa Tutur Guru dan Siswa Kelas X SMA Insan Cendekia Syech Yusuf. Jurnal Idiomatik, 3(1), 35-46.

17. Kbbi.kemdikbud.go.id, (2016, 28 Oktober). KBBI V. Accessed from https://kbbi.kemdikbud.go.id/

18. Baso, S. M. M. (2019). Perubahan Makna Kata Serapan Bahasa Arab dalam Bahasa Indonesia dalam Istilah Keagamaan. Institut Agama Islam Negeri (IAIN) Sorong, Papua Barat.

19. Glottolog.org, (2011), Dialect: Arekan, Accessed from https://glottolog.org/resource/languoid/id/arek1234 